Lejeune A., Ringelheim J., 2019. Workers with Disabilities between Legal Changes and Persisting Exclusion: How Contradictory Rights Shape Legal Mobilization. Law \& Society Review, in production.

\title{
Workers with Disabilities between Legal Changes and Persisting Exclusion: How Contradictory Rights Shape Legal Mobilization
}

\author{
Aude Lejeune \\ CNRS Researcher, Sociology, University of Lille \\ Julie Ringelheim \\ FNRS Researcher, Law, University of Louvain
}

\begin{abstract}
It has become commonplace within disability socio-legal scholarship to argue that, in the last thirty years, a new legal and policy approach to disability has emerged, leading to a paradigm shift from a social protection framework to an antidiscrimination model. Some authors have stressed, however, that the new model has not fully replaced the older social protection approach. Yet little is still known about how the coexistence of these different models impacts on the everyday experience of disability in the workplace and on potential legal mobilization. Based on interviews with workers with disabilities who mobilized the law to obtain reasonable accommodation in Belgium combined with an analysis of evolving Belgian legal schemes relating to disability, this article explores how interactions between social, labor and antidiscrimination rights shape legal mobilization of persons with disabilities in the workplace. We find that individual's initial self-identification as workers or persons with disabilities influences how they frame their claim and the kind of legal norms they refer to in a first stage but that both their identification and their rights consciousness evolve and change through the course of legal mobilization as they interact with various professionals and navigate between the different concepts and rights available in current law.
\end{abstract}

Disability socio-legal scholars have highlighted the emergence and diffusion, in the last thirty years, of a new legal approach to disability, based on the concept of antidiscrimination. According to this new model, people with disabilities should not be seen as physically and mentally impaired persons in need of protection but rather as people endowed with rights and entitled to be included in society on an equal footing with others (Heyer 2015; Kelemen 2011; Shakespeare 2006; Vanhala 2015). This evolution is seen as reflecting the move from a "medical" to a "social" conception of disability and from a "social protection" to an "antidiscrimination" model of disability policy. Heyer (2015), however, has observed that, in various countries, the emerging rights model has not fully replaced the preexisting model based on social welfare. This is true in many European states, where the antidiscrimination framework now coexists with previous legal arrangements, consisting in particular in social allowances, aimed at compensating the supposed disabled person's inability to work (social 
rights). What has been less noticed is that the protection traditionally offered in European welfare states by labor law to workers encountering health problems (labor rights) can also be relevant to the situation of people with disabilities. Moreover, existing literature has neglected how these three bodies of rights - antidiscrimination, social, and labor rights - which rely on different understandings of disability, interact and impact on the everyday experience of disability in the workplace and on potential legal mobilization. Belgium is a case in point to study these phenomena: it is a country with a strong tradition of social and labor rights that passed its first legislation prohibiting disability discrimination in 2003, in line with its obligations as an EU member state. Combining the viewpoints of a legal disability and a sociology disability scholar ${ }^{1}$, our article examines how antidiscrimination rights interact with social and labor rights in the legal mobilization of disabled persons in the workplace in Belgium. It does this by focusing on the use of a specific legal tool emblematic of the new antidiscrimination model of disability policy: the right to reasonable accommodation.

To explore how contradictory rights shape legal mobilization, we first present our theoretical framework that crosses socio-legal studies and disability studies. Part II sets out the methodology and data collection technique used. Part III introduces our case study and describes the relevant features of the Belgian politico-legal context. Part IV analyzes how interactions between social, labor and antidiscrimination rights shape concrete legal mobilization of persons with disabilities.

\section{BEYOND THE 'SHIFT OF PARADIGM' THESIS: HOW COEXISTENCE OF OLD AND NEW RIGHTS IMPACTS ON LEGAL MOBILIZATION}

Academic literature on law, society and disability has so far developed along three main lines, which can be termed the 'law and policy approach', the 'social movements approach' and the 'legal consciousness approach' to disability. Each of these has evolved with relative independence from the others, even if many law \& society and disability scholars try to create bridges between these works. Our theoretical framework draws on these three approaches, while differing from each of them in several respects. While most of this scholarship insists that there has been a radical shift in the handling of disability within law and policy, we underline the persistence of previous models and explore how interactions between old and new rights shape legal mobilization.

\section{The Law and Policy Approach to Disability}

The first perspective we build upon, the law and policy approach to disability, includes political science and legal scholarship that has emphasized the development of a new model

\footnotetext{
${ }^{1}$ This article was written as part of the collective research project Disability and Reasonable Accommodation. Import and Uses of a New Legal Instrument in France and Belgium [in French], with support from the Mission de recherche Droit et Justice (Lejeune et al., 2017). We also wish to thank the anonymous reviewers at Law \& Society Review for their insightful comments on a previous version of this article.
} 
for laws and policies regarding disability. Legal and policy changes are said to reveal a "legal paradigm shift from welfare or social security law towards antidiscrimination or equality law" (Vanhala 2015: 840). They reflect a transformation of the understanding of disability itself, characterized by a shift from the so-called medical model to the social model of disability, which has been actively promoted by disability activist movements (Driedger 1989; Heyer 2015; Shapiro 1994). Under this new approach, rather than an intrinsic characteristic of the person, which would make them objectively incapable of integrating into mainstream society, disability is seen as the result of the interaction between disabled persons and their physical, social and institutional environment, which is not adapted to their needs (Barnes \& Mercer 2005; Oliver 1996). Whereas previous policies were focused on the provision of social allowances, the creation of separate institutions (like sheltered workshops), rehabilitation and employment quotas, the new legal framework is based on the idea that disabled persons should have the right to equal opportunities and inclusion within the wider society. This entails the prospect that the environment may have to be adapted to accommodate their needs. The Americans with Disabilities Act (ADA), signed into law in 1990, is considered the first comprehensive national legislation reflecting this new antidiscrimination approach. It has become a source of inspiration for both activists and policy-makers around the world (Heyer 2015; Kelemen 2011; Kelemen \& Vanhala 2010). The legal recognition of a right to reasonable accommodation is emblematic of this new focus on inclusion, equality and rights. Scholars have shown that the ADA has largely influenced the evolution of European Union law in relation to disability (Burke 2004; Quinn \& Flynn 2012). From the mid-1990s onwards, the antidiscrimination framework has gained prominence in this context as well (Halvorsen et al. 2017; Waddington 1996; Waldschmidt 2009), culminating in the adoption of Directive 2000/78/EC (the so-called "Employment Equality Directive"), in 2000. This Directive requires all EU member states to prohibit discrimination in employment and occupation, based inter alia on disability, and to establish a duty for employers to provide reasonable accommodation to meet the needs of disabled workers (Mabbett, 2005). It has largely contributed to the diffusion of the antidiscrimination approach to disability throughout Europe (Cohu, Lequel-Slama \& Velche 2005; Waddington 2008). The new antidiscrimination approach to disability also reached the UN level where it greatly influenced the drafting of the UN Convention on the Rights of People with Disabilities (2007) (Quinn \& Flynn 2012).

While most of these studies on law and policy focus on the content of policies and legislation or the case-law looked at in isolation, our research emphasizes concrete legal mobilization and rights claims, from the perception of injustice to court decisions. We examine how people with disabilities come to define themselves as disabled and how they mobilize the law, taking into account the multiple and sometimes contradictory definitions of disability and rights associated with it available in current legislation.

\section{The Law and Social Movements Approach to Disability}

Our framework is also inspired by a second line of research, namely the law and social movements approach to disability. For more than forty years, socio-legal scholars have studied the use of legal strategies and their impact on social changes (Handler 1978; McCann, 1994; Rosenberg 1993), and some have specifically focused on disability rights mobilization. Investigating the different factors that have led disability rights organizations to strategically use the courtroom (Vanhala 2011), they have highlighted two main factors. First, until the 1970s, many disability organizations were run by non-disabled persons who had a special motivation to represent their interests: family, relatives or professionals. Since then, a 
growing number of organizations have come to be run by people with disabilities themselves, who have strongly contributed towards challenging the traditional medical approach to disability and fostering instead a discourse emphasizing equality, rights and inclusion (Shakespeare 2006; Vanhala 2009). In this context, litigation has come to be seen as one of the most appropriate ways of promoting their cause. Second, studies have stressed the impact of new legal opportunities made available as a result of certain legal reforms, i.e. changes in the rules of standing (Heyer 2015) or the recognition of new rights, like the right to reasonable accommodation (Burke 2004; Mabbett 2005; Vanhala 2011).

The literature on law and social movements has largely explored high-profile litigation, focusing on cases supported by large NGOs that have reached higher or supreme courts (Setzer \& Vanhala, 2019, p. 5). These NGOs used litigation with a political agenda; their goal was to produce social and policy change. In our study, by contrast, we focus on legal mobilization by workers who had few connections with disability activists, but nevertheless have formally contested a denial of reasonable accommodation. Following Morrill et al. (2010), we understand legal mobilization as "the social processes through which individuals define problems as potential rights violations and decide to take action within and/or outside the legal system to seek redress for those violations" (Morrill et al. 2010: 654). Accordingly, we include in this study not only workers who brought their case to courts but also those who merely contacted a lawyer or lodged a complaint with the public agency tasked with monitoring discrimination issues in Belgium (the "equality agency"), called the Center for Equal Opportunities.

\section{The Legal Consciousness Approach to Disability}

The third perspective we draw on is the legal consciousness approach to disability. Socioanthropologists have explored the everyday experience of ordinary citizens with law or, in the words of Ewick and Silbey (1998), "legality". Based on biographic narratives produced by people with disabilities, Engel and Munger (2003) analyzed how the ADA influenced their experience of disability in various situations. Following other studies on legal consciousness (Ewick \& Silbey 1998; Merry 1990), they paid attention to situations in which people with disabilities did not mobilize the law nor even explicitly make reference to legal norms. They showed how law produces identities and influences the ways disabled people understand their inclusion within society. Revillard (2017a) has taken this perspective beyond the United States and explored the impact of policy changes on disabled people's everyday life in France. Dorfman (2017) has investigated how identities influence the perceived fairness of the official process through which people with disabilities have to pass when asking for Social Security benefits in the US. These works have imported into the socio-legal scholarship the idea that disability is a cultural, social and political phenomenon that contributes to the production of collective significances and representations (Goffman 1963; Heyer 2007).

This body of literature has primarily been concerned with analyzing how legality shapes ordinary life. Engel and Munger, in particular, aimed at studying how rights "can become active in everyday life in many different ways - not just when an individual decides to sue or assert a claim explicitly" (1996: 43). Thus, they have intentionally left unexplored the question of how these various experiences with rights can, in some cases, lead to formal rights claims. We do not contest their argument that there is a gap between the experience of injustice and the assertion of legal rights. This hypothesis has also been demonstrated in other fields (Albiston 2005; Felstiner, Abel \& Sarat 1981; Marshall 2003; Morrill et al. 2010). We 
do not deny either that rights can be active without any formal protest (Engel \& Munger 1996). However, we explore another dimension of disabled workers' experiences with legality, namely how they come to mobilize the law to contest a perceived unfairness relating to their disability, what type of rights they invoke and how their self-identification and understanding of disability shape the way they mobilize the law while being themselves shaped by their experience of legal mobilization.

\section{How Contradictory Rights Shape Legal Mobilization}

Despite their difference of focus and methodology, the three strands of literature described above share the idea of a paradigm shift from a social protection approach to an antidiscrimination or rights-based model of disability policy. Our research stands out in this regard in that it emphasizes the persistence of previous approaches to disability in spite of legal and policy changes. Some scholars have already noted this phenomenon. Heyer (2015), in particular, has observed that in various countries, the introduction of the rights model has not led to the disappearance of the social protection model, thus leading to a pluralization of policies related to disability with possible contradictions between them (see also Quinn \& Flynn 2012). Others have argued that the relation between social welfare and antidiscrimination approaches should be understood in terms of layering instead of replacement (Aucante \& Baudot 2018; Baudot 2018). We, however, move the focus from disability law and policies to concrete legal mobilization. Moreover, we stress the relevance for workers with disabilities, not only of social rights, which include the right of people unable to work to receive social allowances, but also of labor rights, which in many countries encompass some protection for workers encountering health problems. The new, much broader, understanding of disability on which the antidiscrimination framework relies means that, in many cases, what was previously seen as "sickness" or "limitations due to health condition" can now also be framed, from a legal viewpoint, as "disability." Workers in such situations may invoke different legal frameworks, each of which is associated with different rights but also with different collective frames of reference, identities and histories. Against this background, our aim is to explore how the coexistence of, and interactions among, social, labor, and antidiscrimination rights in Belgium influence the experience of disability and shape legal mobilization of workers seeking to obtain an adaptation of their work conditions in view of their disability.

\section{METHOD}

Our investigation is based on socio-legal methods of research. We conducted interviews with twelve workers with disabilities who filed a complaint before the equality agency or initiated legal action to contest a denial of reasonable accommodation between 2014 and 2017 in Belgium (one or two interviews per person) ${ }^{2}$. Thus, we only selected people who had formally contested a violation of their rights. Our research population therefore only reflects a minority

\footnotetext{
${ }^{2}$ Aude Lejeune conducted all the interviews.
} 
of Belgian workers with disabilities: those who pursued their rights through formal complaint. But this selection is consistent with the aim of our enquiry, which is to explore the conditions under which some workers do turn to law - and more specifically disability discrimination law - and the effects this experience of legal mobilization has upon them. Moreover, we sought to gather interviewees with varying backgrounds and who had contacted different sorts of legal professionals and organizations in the course of their mobilization. Accordingly, we used various intermediaries: private lawyers; labor judges; legal officers of the Center for Equal Opportunities; and social workers from various NGOs who assist people with disabilities. Contrary to many studies on disability, our research does not focus on one type of disability; it includes workers in a wheelchair, with multiple sclerosis, or with evolving blindness. This does not mean that we consider disability to be a homogeneous category. We are aware that, as Engel and Munger observed, "different kinds of disabilities have very different effects on the lives, including the employment experiences" (1996: 17). Our concern, however, is to analyze the process through which individuals with different types of disability, identities, and experiences in the workplace, come to mobilize the same legal instrument: the right to reasonable accommodation.

During the interviews, we asked these workers to speak about their professional training, background, and experience of disability in the workplace and in everyday life. We also asked them to narrate how they decided to mobilize the law and their interactions with various sorts of professionals. We questioned them about their beliefs, hopes, and knowledge about the litigation or negotiation process, as well as their representations of current disability policies, workplace, and equality. We refer to the accounts produced by the workers we met as "stories". We do not use the term "narratives" as Engel and Munger (1996) did because our method differs from the one they employed. Although we also used open-ended interviews, we were specifically interested in situations of perceived injustice and conflicts in the workplace. This was explicitly mentioned to the interviewees and therefore influenced the story they told us.

Besides, in order to situate such mobilization in its wider context, we carried out a thorough study of the evolution of the Belgian legal schemes relevant for workers with disabilities. We investigated the evolution of legal provisions relating to social, labor and antidiscrimination norms in this regard as well as the varying rationales underlying these legal texts. Importantly, many features observed in the Belgian case are shared by other EU countries.

\section{DISABILITY RIGHTS IN BELGIUM: EU MEMBERSHIP, WEAK DISABILITY MOVEMENT AND STRONG LABOR LAW TRADITION}

The literature on disability rights mobilization has, to a large extent, been developed by US scholars. Accordingly, this work takes for granted a number of social, political and legal features that characterize the US but that do not necessarily apply to other national contexts. Studying mobilization relating to disability rights in Belgium offers the opportunity to put this literature into perspective and highlight some of its assumptions that are specific to the US context. In this section, we first emphasize key similarities and differences between Belgium and the US in relation to disability rights in employment. We then look at the evolution of the Belgian legal framework relating to disability, its multiple rationales and the interrelations between labor rights, social rights and antidiscrimination rights in this context. 


\section{Antidiscrimination, Disability Movement and Work Relations}

Disability law and policy in the US and Belgium share a number of similarities. In both countries, legal provisions prohibiting disability discrimination and recognizing denial of reasonable accommodation as a form of discrimination have been adopted. In the US, this transformation occurred most prominently in 1990 with the aforementioned ADA. In Belgium, these new legal concepts were introduced as a result of the adoption of the Employment Equality Directive by the European Union. They are now enshrined in the federal law on combating certain forms of discrimination, passed on May 10, 2007. ${ }^{3}$ This law defines the notion of "reasonable accommodation" as follows:

"appropriate measures, taken according to the needs in a concrete situation, to enable a disabled person to have access to, participate in, and advance in the fields to which this law applies, unless such measures would impose upon the person who shall adopt them a disproportionate burden." 4

Similarities between US and Belgian legislation also extend to enforcement methods. In both cases, litigation is the primary means of enforcement envisaged by the law. Burke and Barnes argue that in the US, the "civil rights template" has been prevalent in relation to disability rights as "a public policy model in which social injustices are addressed through lawsuits that aim to punish individual acts of discrimination" (2016). In Belgium, the law mirrors the Equality Employment Directive system relying mostly on a litigation-based model of enforcement (Amiraux \& Guiraudon 2010). The directive requires member states to ensure that adequate judicial remedies are available to all persons who consider themselves wronged by a violation of antidiscrimination provisions and to make sure that relevant associations have legal standing in such procedures. ${ }^{5}$ A final common feature is that, in both countries, a public agency has been set up to monitor compliance with antidiscrimination statutes. The status and powers of the US Equal Employment Opportunities Commission (EEOC) and of the Belgian Center for Equal Opportunities differ but both are responsible for assisting victims of disability discrimination. The Belgian Center is entitled to receive individual complaints. Where complaints are deemed well-founded, the agency initiates a mediation process aimed at arriving at an arrangement agreed by both parties. In case of failure, the Center may encourage the victim to sue or, in rare cases, bring the case to court in its own name (Lejeune \& Orianne, 2014).

There are important differences between the Belgian and US social, political and legal contexts in which these legal concepts and institutions operate. A common assumption in US disability studies is that legislative changes reflecting the move from social protection to antidiscrimination are a direct response to the mobilization of disability activists. In contrast, the Belgian experience with antidiscrimination law is less reliant on mobilization. Similar to

\footnotetext{
${ }^{3}$ The prohibition of disability discrimination was established by a federal law passed on February 25, 2003, which was replaced by the May 10, 2007 law.

${ }^{4}$ Art. $4,12^{\circ}$.

${ }^{5}$ Art. 9.
} 
other EU states, the introduction of disability antidiscrimination mandates, including the right to reasonable accommodation, was the result of the EU's adoption of the Employment Equality Directive, rather than of disability activism and legal mobilization on the ground. Disabilities activists played an important role in lobbying for a disability antidiscrimination approach at the EU level, but this was not matched at the national level (Burke, 2004; Mabbett, 2005). In Belgium, the legal recognition of a right not to be discriminated against based on disability was thus a top-down, rather than bottom-up, process. This explains why Belgian organizations and lawyers specializing in disability issues were unfamiliar with these new concepts when they were introduced in domestic law. As a result, it is the Center for Equal Opportunities, rather than NGOs, that plays a leading role in the diffusion of the antidiscrimination approach to disability in Belgium.

A second element commonly taken for granted is the existence of civil society organizations actively involved in the defense of disability rights including through litigation. Contrary to their US and other common law counterparts (Revillard, 2017b; Vanhala, 2011), Belgian disability organizations rarely use the courts. This situation can be explained by the historical trajectory of the disability movement. Early $20^{\text {th }}$ century disability organizations were typically oriented towards philanthropic activities (Vrancken \& Bartholomé, 2004). From the 1930s onwards, the Belgian state gradually delegated disability service provision to the nonprofit sector, and allocated financial resources to this effect. Disability organizations began to play a major role in the fulfillment of administrative and practical tasks but did not developed as advocacy groups that challenge disability policies. As observed in other countries, some grassroots activist groups however emerged (Bagenstos, 2009; Fleischer \& Zames, 2011), but they focused on political actions, such as sit-ins in front of government buildings or lobbying in parliament, rather than legal action before courts. This reflects a wider phenomenon observable throughout Europe: in many countries, the possibility for associations to initiate proceedings for discrimination - which under EU law, all member states have to provide for is, in practice, rarely used by NGOs. This has been attributed to procedural and material barriers (such as respectively limited rules of standing and lack of resources) but also to differences in mobilization cultures among European NGOs compared to US ones (Amiraux \& Guiraudon, 2010). Significantly, in Belgium, among the case-law issued so far in relation to the right of disabled workers to reasonable accommodation, we could not identify any lawsuit formally brought by an NGO (Ringelheim, 2018). All cases were brought by individuals with the assistance of their private lawyer and/or the Center for Equal Opportunities, except for one case which was introduced by the Center itself ${ }^{6}$.

A third assumption implicit in the US disability literature is that antidiscrimination law is the strongest legal tool available to protect workers from unfair treatment. This might reflect the situation in the US, which has one of the least regulated workplaces of the industrialized world and where labor rights are especially weak (Befort, 2018). In contrast, Belgium, like other continental Western European countries, has a relatively strong labor legislation that is based on the idea that, given the imbalance of power characterizing the employment relationship, all workers, and not only those belonging to certain vulnerable minorities, need

\footnotetext{
${ }^{6}$ Liège Labor Court, Decision of March 9, 2018 (RG 17/22/C).
} 
to be protected against abuse of power by the employer. As labor rights benefit from a longer tradition than antidiscrimination rights in Belgian law, they are more anchored in work culture and practices. Additionally, trade unions remain an important player in work relations. A complex system of dialogue and negotiations among unions and employers' organizations is in place. Union membership, evaluated at 52\% (Faniel \& Vandaele, 2012), is relatively high, and considerably higher than the US rate of 10.7\% according to 2017 figures (Befort, 2018). Hence, in case of dispute with their employer, workers often turn first to union delegates or labor lawyers for support.

\section{Interrelations between Labor Rights, Social Rights and the Right to Reasonable Accommodation in Belgium}

Workers facing health difficulties have long benefited from specific protections under Belgian labor law. The Law of July 3, 1978 on employment contract specifies that the inability to perform work as a result of sickness or accident does not entail the termination of the employment contract but only its suspension for the time necessary to the worker's recovery (Art. 31). Workers are entitled to paid sick leave, the cost of which is provided by the employer or social security institutions, depending on the length of the leave. Yet, until recently, workers who were declared permanently unable, for health reasons, to perform their work as defined in their contract had no protection against dismissal. According to a 1981 ruling of the court of cassation, the highest court in the Belgian judiciary, such occurrence constituted an instance of "force majeure" which triggered the cancellation of the contract, with the consequence that, contrary to the ordinary procedure, these workers could be dismissed without notice or compensation. ${ }^{7}$ This was known as the "medical force majeure." Unlike French labor law, for instance, Belgian legislation did not require employers to ensure the professional redeployment of workers in such a situation.

This approach reflected a binary vision in which people are seen as either fit or unfit for work, in which case their exclusion from the workplace was considered natural and legitimate. Their exclusion was compensated by a web of social rights: those excluded from employment and unable to earn a living are entitled to social benefits, such as unemployment benefits and a disability allowance. To qualify for the allowance workers must be recognized for having lost at least $66 \%$ of one's capacity to work. ${ }^{8}$

As noted by Quinn and Flynn, "[1]arge elements of the European 'welfare model' had been built on the assumption that human deficits simply exist and have to be 'compensated' for through wealth transfers" and "there was an assumption that disability automatically equated with deficits." (Quinn \& Flynn, 2012, p. 30; Mor, 2005). Significantly, this model relies on a close relation between labor rights and social rights; while the former protect those who are employed, which is considered the "normal" status of a person of working age, the latter guarantee means of subsistence to those who lost their job or are unable to work.

\footnotetext{
${ }^{7}$ Cass., January 5, 1981, Pasicrisie, 1981, I, p. 474.

${ }^{8}$ Law of February 27, 1987 on allowances for disabled persons.
} 
The idea that workers with health problems or impairments could not be accommodated was not uncontested, however. The Law of August 4, 1996 relating to the well-being of workers already mentions the objective of "adapting work to the person". 9 A royal decree adopted on May 28, 2003 on the basis of this law established that when a worker was declared permanently unable to perform work, the employer had to continue employing this worker and to assign them to a different job, upon recommendation by a physician, unless this was not technically or objectively possible or could not reasonably be required for another duly motivated reason. The question arose as to whether this provision really imposed a legal obligation on employers to try professional redeployment before being allowed to terminate the contract due to "force majeure." Judges and experts were divided on this issue and contradictory rulings were issued (Neven, 2013). This shows the strength of the resistance opposed to a limitation of the employer's discretion to dismiss workers facing permanent impairments. At the same time, these provisions reveal that a counter-discourse had already developed from within labor law prior to the recognition of a right to reasonable accommodation as part of the antidiscrimination approach to disability.

In comparison to preexisting protections of workers encountering health problems, the recognition of a right to reasonable accommodation offers an important new protection. First, this right may benefit persons with disabilities seeking a job and not merely those already employed. Second, given the broad understanding of disability under antidiscrimination law, workers who are declared permanently unable to perform their work can be considered "disabled persons" within the meaning of this law and thus benefit from the right to reasonable accommodation. According to the interpretation criteria agreed upon in 2007 by federal and state governments, disability, for the purpose of reasonable accommodation, must be understood as "any lasting and important limitation to the participation of a person due to the dynamic interaction between (1) impairments of a mental, physical, psychological or sensorial nature, (2) limitations in the execution of activities and (3) personal and environmental contextual factors." 10 This document explicitly states that not only persons recognized as disabled by previous legislation - which required reaching a threshold of disability - are considered as persons in situation of disability with respect to the right to reasonable accommodation. This approach is reinforced by Belgium's ratification of the UN Convention on the Rights of Persons with Disabilities, which also refers to the interaction between personal impairments and barriers created by the social environment as a determining criterion of disability (see art. 1, al. 2). The Court of Justice of the European Union has adopted a similar approach in its case law interpreting the concept of disability under EU antidiscrimination law. ${ }^{11}$ Now, as seen, under previous legislation, many judges and experts considered that the law permitted the dismissal of disabled workers without notice or compensation, based on the "medical force majeure" rule. This happened despite attempts by the legislator to encourage employers to continue employing workers declared permanently unable to perform their work while offering them a position adapted to their medical

\footnotetext{
${ }^{9}$ Art. 5(1)(f), our emphasis.

${ }^{10}$ Protocol relating to the concept of reasonable accommodation in Belgium under the Law of February 25, 2003 aimed at combating discrimination, Art. 2.

${ }^{11}$ See cases C-335/11 and C-337/11 Jette Ring and Lone Skouboe Werge, para. 41.
} 
condition. The antidiscrimination law, by contrast, makes clear that employers have a legal duty to provide reasonable accommodation: they must take "appropriate measures" to allow a disabled person to access, participate or advance in employment, unless this entails a disproportionate burden. And this also applies in case a worker becomes disabled after they started to work for a given employer.

This implication of the antidiscrimination legislation was not immediately perceived by most labor law specialists (Neven, 2013) and still remains little known by workers, employers, union delegates and labor law lawyers (Lejeune et al., 2017). Labor rights and antidiscrimination rights represent two separate legal frames of reference with different traditions, logic and specialized actors. The introduction of the antidiscrimination framework has not resulted in the disappearance of pre-existing legal schemes relating to health at work, professional integration of disabled persons and provision of social allowances based on disability, which were framed in the language of labor and social rights. These different categories of rights now co-exist in Belgian law, including varying definitions of disability. While the antidiscrimination law relies on a social understanding of disability, special professional integration measures (like professional rehabilitation programs, quotas in the public sector or sheltered workshops) and social allowance legislation usually rest on a medical approach, based on varying thresholds of incapacity. ${ }^{12}$

\section{HOW SOCIAL, LABOR, AND ANTIDISCRIMINATION LEGAL NORMS SHAPE LEGAL MOBILIZATION}

In this section, we explore how workers with disabilities experience injustice resulting from their employers' refusal to adapt their work environment, tasks or schedule to their disability and how social, labor, and antidiscrimination rights shape their mobilization to contest this refusal. Following seminal works on the emergence and transformation of disputes (Felstiner et al., 1981; Miller \& Sarat, 1981), we consider disputes as a process during the course of which the claims made and the arguments invoked can change and which may or may not result in a legal action before courts. However, rather than on the successive stages of the dispute process, our analysis is structured around three dimensions of the mobilization, which allows us to better highlight how the coexistence of different types of rights affects the legal mobilization of workers seeking reasonable accommodation. First, we examine how individuals' self-identification to collective categories like workers or persons with disabilities impacts their perception of the injustice and the kind of arguments they use to contest it. Second, we analyze how the claim made, the rights invoked, and the attitude towards the law evolve in the process of mobilization. We emphasize in particular the impact

\footnotetext{
${ }^{12}$ After the adoption of the antidiscrimination legislation, an important reform of the regulation of work incapacity was passed in 2016. In an effort to reduce long-term work incapacity and its public cost, this reform created a reintegration program for workers temporarily or permanently unable to perform the agreed work. This reform, was not yet in force when the present study was carried out.
} 
of interactions with different sorts of professionals on this evolution. Third, we look at the effects of legal mobilization on individuals concerned.

Among our interviews, we have selected four stories. We do not consider them as ideal-types that exhaustively cover all the possible paths followed by workers who mobilize the law to obtain some form of accommodation at work in view of their disability. However, we have chosen them because they reveal significant differences in how individuals who come to invoke the same legal concept, the right to reasonable accommodation, experience the various dimensions of legal mobilization (see table 1). Furthermore, for each dimension studied perception of injustice, process of mobilization, and effects of mobilization - , these four stories allow us to highlight explanatory variables that form common patterns in our twelve cases (see table 2).

\section{Self-identification and Perception of Injustice}

Self-identification as a member of a collective category influenced the perception of injustice by our interviewees, which in turn impacted on how they framed their claim and mobilized the law. In the four stories, we observe variations in the categories our interviewees used to identify themselves, but we also find that such identification can change over the course of the dispute. Each story has its own specificity in this regard: in the first case, the interviewee identified as a worker with health problem rather than disabled; in the second, the person considered herself as a worker with disability; in the third, the interviewee persisted in her identification with disability despite being denied official recognition as disabled under social legislation. The last story is specific in that the person already identified as disabled prior to his entrance in the labor market. Importantly, in all four cases, the individuals concerned experienced at some point in their life a change in their physical conditions but the legal framework affected differently how each of them understood this experience.

\section{Identifying as a Worker with Health Problems}

Fifteen years ago, Bart Janssens ${ }^{13}$ was diagnosed with multiple sclerosis (MS) when he worked in a blue-collar job at a large construction factory. He informed his employer of this diagnosis, but told only a couple of colleagues about it. When we met him, he remembered that he went through hard periods of time when he had attacks of MS but concealed his condition from his colleagues. After a few years, he was in so much pain that he went to see the occupational physician, who told him that he would be declared unable to perform his work because he was no longer able to work as construction worker in his department. A few days later, a human resources officer informed him he would be dismissed for medical reasons. "He told me that it was the regular procedure when you are unable but... I could not be unemployed. My wife had just lost her job." He decided to contest his physician and employer's decision and started a long fight with his employer to stay in employment and be moved to another department, following the ordinary procedure of internal transfer. In this conflict, Bart Janssens primarily defined himself as a worker who had to face health problems as a new challenge in his professional life. Significantly, during our first interview, he used

\footnotetext{
${ }^{13}$ Names were changed to guarantee anonymity of interviewees.
} 
almost exclusively the terms "chronic illness" or "health condition." He first mentioned the word "disability" after more than two hours, when he talked about the moment he learned that discrimination "concerned not only racism but also disability." While he did come to invoke the legislation on disability discrimination in his dispute with his employer, he did not identify himself as disabled but considered his recognition as such as a strategy in order to stay in the company. "I do not think that I am disabled yet. It is true that I don't walk as much as I did a few years ago. But disabled... not yet. At work, it was different. I could not keep on working as I did before. I was working on construction sites you know. [...] Being recognized as disabled, well, it helped me to force [my employer] to do something." In his view, he had to slide into the category of people with disabilities in order to convince his employer to keep him in his company. However, he made a clear distinction between the recognition he asked for as a strategy to stay in employment and his personal identification: "When you are recognized as disabled, it does not mean that you are. [...] But it can help in your negotiations."

\section{Progressively Identifying with Disability as a Worker}

In comparison with Bart Janssens, who accepted being recognized as disabled for strategic motives but continued to personally identify as a worker with health problems, Marie Petteni gradually came to identify as disabled and, along this process, started to read her experience as injustice based on disability. Marie Petteni had worked as a teacher in different elementary schools for three years when she was diagnosed with multiple sclerosis. The first year, she had several attacks and felt very tired so she asked the school director if she could teach in the classroom located on the first floor and have all her spare time grouped together so that she could have one afternoon off every week. The director refused, arguing that it amounted to giving her special treatment in comparison with other teachers. She knew from the beginning that her health condition would get worse, because her mother had the same condition, having been diagnosed thirty years earlier. At that time, she had no idea about her rights but knew that she would fight to stay in employment. "Well... I am divorced and raising my daughter by myself. This is not the same situation as for my mother a generation ago. [...] I had to keep my job." Following the recommendation of her occupational physician, she contacted the regional institution in charge of disability. Through her interactions with this institution, she progressively started to identify with disability.

\section{Identifying as Disabled Despite Being Denied Official Recognition as Disabled}

In comparison with the two previous stories of workers who were diagnosed while they were already in employment, Charlotte Leroy had a stroke when she was twelve that damaged her optic nerve. She has had three surgeries since then but still faces eyesight troubles. When her physician advised her that additional surgery would not improve her eyesight, she decided to put in an application at the Disability Regional Office and was recognized as being 33\% disabled. This was below the $66 \%$ loss of work ability required to be eligible for disability benefits. "I have always been disabled, but I had never asked for the recognition because I did not need it. [...] When I asked for it, the big problem [was] that my disability [was] not recognized as sufficient by the [disability office].” This decision did not put her identification as having a disability in doubt; on the contrary, it even reinforced her conviction that she was disabled but with a particular type of condition that is not sufficiently recognized. In the workplace, she was employed in the administrative staff of a non-profit organization that managed several hospitals. Among other tasks, she had to encode results of various blood and 
medical tests. As she had eyesight troubles when she worked for a long time on a computer, she asked her occupational physician if she could benefit from a "medical part-time" scheme, an option offered by social legislation to work part-time after a period of sick leave and receive social security benefits as a complement to the salary paid by the employer. The physician told her that she did not fill the conditions to benefit from this scheme. She then asked her employer to have her tasks redefined in order to spend less time on a computer. As the hospital refused, she asked to be transferred to another position and was put on medical leave. After a few months, her employer suggested that she sign a conventional termination of her employment contract. She accepted and signed. But a few days later, she contested this conventional termination because she believed that her employer ought to have tried to move her to another position. Through this dispute with her employer, she had to confront her selfperception with contradictory legal definitions of disability. She was not recognized as disabled under the social legislation relating to disability benefits as she had lost less than $66 \%$ of capacity to work. She discovered however that she could claim reasonable accommodation on the grounds of disability under antidiscrimination law.

\section{Identifying with Disability before Entering the Labor Market}

François Tiquet was diagnosed with evolving blindness right after he obtained his college degree. He started to work when he was already diagnosed with evolving visual impairment. He began as a sales manager and occupied various positions in different companies, without any difficulty related to his disability. "At that time, my visual impairment did not handicap me; it was not an issue. I could work like my other colleagues, without any accommodation." Then he traveled to the US and Japan, where he worked as a sales officer for a few years. While he was there, his visual impairment worsened so he asked for reasonable accommodation and immediately received an adapted computer screen. During his stay abroad, he learned about the disability rights movement and the social construct approach to disability. When he came back to Belgium, he started to look for a job. He sent many application letters but did not receive any answer. He decided to remove the mention of his disability from his letters and received several invitations to job interviews. When he was about to sign his employment contract with a large retail company, he revealed he had a disability. The employer told him that he could not hire him because sales managers had to be able to drive their company vehicle. Having learnt during his experience abroad about the legal duty of employers to provide reasonable accommodation, he decided to contest this decision.

As illustrated by these four stories, our interviews put into light two factors that shape the perception of injustice. First, self-identification primarily as a disabled person or as a worker influences how individuals perceive the injustice they experience at work. Some felt the injustice was related to disability, while for others, it was an issue of health condition. Yet identification as disabled or not disabled is not given once and for all. It can evolve and change. As Heyer puts it, "disability is a fluid and open category - anybody can join at any time - and it does not conform to the limitations of traditional identity categories that assume lifelong assignments" (2015, p. 61). For some of our interviewees, self-perception as disabled began the moment they learned about their impairment; for others, it took time before they started to identify with disability and this process was prompted or reinforced by the legal definition of disability offered by antidiscrimination law. Some, however, continued to refuse to self-identify with disability even while they were invoking the right to reasonable accommodation. A second explanatory factor of the differing attitudes among our 
interviewees towards perception of injustice lies with the kind of work environment they found themselves in. Bart Janssens was a blue-collar worker whereas Marie Petteni was a white-collar employee. They both developed the same disease at about the same age, yet they differed in their propensity to identify with disability and, accordingly, to perceive their own experience as an injustice linked to disability. In our other interviews as well, we found that blue-collars workers were more reluctant than white-collars ones to identify with disability. Significantly, we also observed that the former were more likely than the latter to see disability and work as incompatible.

\section{Legal Mobilization as a Process}

All our interviewees share in common the fact that they sought to obtain from their employer an adaptation of their work conditions in view of their disability. But they differed in the way they framed their claim and the types of rights they put forward, as well as their readiness to use the law and legal action. At the same time, most of them evolved in these different respects over the course of the mobilization. Three aspects of this process are examined here: the role of professionals; changes in rights consciousness; and the manner in which law is mobilized.

\section{The Role of Professionals}

In other fields, socio-legal studies have already explored how competing legal and extra-legal frameworks, supported or weakened by various actors involved in the labor market - i.e., labor unionists, employers or colleagues - influence the process of rights claims (Albiston, 2005; Marshall, 2003). Throughout the dispute with their employers, the workers we interviewed surrounded themselves with professionals involved in various organizations, institutions, and social movements. Their choice to turn to one professional or another was related both to how they perceived injustice and to how they identified themselves with larger groups, i.e., as workers and/or persons with disabilities. Comparing the cases of François Tiquet and Bart Janssens allows us to illustrate this point. As François Tiquet primarily defined himself as a job applicant who was discriminated against because of his visual impairment, he first turned to professionals specialized in disability issues, namely the nonprofit disability organization he knew, which assists visually impaired persons in their everyday life. By contrast, Bart Janssens first got in touch with professionals who assist all workers, namely his union delegate and human resources manager. He took some time to contact the Disability Regional Office because he refused to view himself as disabled. Finally, following the advice of his union delegate, he contacted the Center for Equal Opportunities, which informed him that he was entitled to claim discrimination based on disability for lack of reasonable accommodation.

In turn, their contacts with professionals shaped the way workers understood their rights in the workplace. Depending on these professionals' support - or lack of support - and advice, workers felt confident or uncertain about their claim and decided to keep on or to give up struggling to obtain accommodation. In the four stories presented here, social workers from disability organizations and trade union representatives did not themselves assist the persons concerned in filling out a formal complaint or bringing their case to courts. However, they indirectly played a significant role in the process that led our interviewees to invoke the right to reasonable accommodation because they informed them about the antidiscrimination law or the legal support they could receive from the Center for Equal Opportunities. 


\section{Continuities and Breaches in Rights Consciousness}

While some workers had a clear understanding of the disability rights movements and the duty of employers to accommodate the workplace before they decided to contest their employer's decision, others reported an evolving consciousness about their rights. Comparing the three following stories allows us to illustrate how, during the course of mobilization, workers evolve as to their knowledge of their rights and, accordingly, the way they frame their claim.

François Tiquet had a clear understanding of the main debates in the disability rights movement and the current disability policies in Belgium, even before he experienced discrimination in hiring. As he had worked in the US and in Japan and benefited from reasonable accommodation in both countries, he knew that the decision of the employer to go back on his employment offer constituted discrimination based on disability and was therefore illegal. Interestingly, he compared his experience with that of African-Americans who were discriminated against in the US, considering his case and theirs as equivalent because they both revealed a lack of integration of minority groups within the society.

In contrast with this relatively constant perception of his rights, Marie Petteni clearly experienced an evolution in her understanding of her rights that conduced her to simultaneously claim equal treatment and social protection. When she first asked her school director to have all of her spare time on the same afternoon every week, she thought she was negotiating privileges over other colleagues. "I felt a little bit guilty... because all my colleagues wanted to have the perfect schedule with several hours of spare time in the same day." When a Disability Regional officer explained to her that she was entitled to benefit from accommodation of her classroom and schedule, and that the employer could ask for financial compensation for this accommodation, she thought that "it became magic. Everything I needed was possible." Throughout the course of her interaction with the disability office, she progressively acquired knowledge about her rights and changed her perception of the situation. She started to consider that schedule adaptation was not a privilege but a right because she had a disability. "[My school director] had to take into account the fact that I needed to go to the hospital quite often, and that I needed some rest during the week [...] because of my condition. It was not a privilege, it was necessary for me to keep on working." At the same time, following the advice of the occupational physician, she also asked for a medical part-time scheme, an option offered by social legislation.

Bart Janssens also shifted his understanding of his rights and, as a result, the framing of his claim. After unsuccessful negotiation with his employer to be moved to another department, he was about to be dismissed for medical reasons. His labor union delegate advised him to turn to the Center for Equal Opportunities for assistance. Bart Janssens filed a complaint and met with a legal officer from the Center who told him he could be considered a victim of discrimination based on disability. From that moment, while maintaining the same demand in its substance, he modified the legal discourse he relied upon. While initially his request was to be moved to another department through the regular procedure of internal transfer, thus using the language of labor law, from then on, he adopted the language of antidiscrimination rights. Doing so, he accepted identifying strategically with the category of persons with disabilities in order to benefit from the protection attached to it. He started to talk about disability and the right to reasonable accommodation, instead of health problems and inability to work. He told us that this was aimed at pressurizing his employer. In effect, he thought that the threat of 
bringing the case to court played a significant role in convincing his employer to assign him to another department.

The evolving rights consciousness of our interviewees was influenced both by their interactions with professionals and, for some of them, the reinforcement of their selfidentification as disabled. All the workers we met had few connections with disability activists when they experienced injustice and decided to do something about it. Most of them were not initially aware that they could rely on antidiscrimination law and the right to reasonable accommodation. But their efforts to get access to, or remain in, employment led them to develop contacts with various kinds of professionals, who informed them that this legislation could help them achieve their goals. In particular, they made them realize that antidiscrimination norms would afford them a better protection than labor law provisions concerning workers encountering health problems. Thus, through their interactions with these professionals, our interviewees progressively sophisticated and diversified their rights consciousness.

\section{Mobilizing the Law, Inside and Outside Court}

Many interviewees talked about their hesitations and doubts before deciding to formally claim their rights. They usually started by negotiating with their employer on their own and it was only when the negotiation failed that they decided to lodge a formal complaint before the Center for Equal Opportunities or to turn to the labor court. Comparing three stories, we explore different experiences of mobilizing the law and, in this process, of relating to social, labor and antidiscrimination rights.

François Tiquet took the initiative to report discrimination and filled out the complaints form on the Center for Equal Opportunities website. He indeed saw himself from the start as a victim of discrimination based on disability. The legal argument made by the legal officers of the Center reinforced his understanding of his experience as a denial of reasonable accommodation. However, when he first got in touch with the Center, he had no idea that he was entitled to ask for financial compensation and was not thinking about taking legal action. He believed that the equality agency played a significant role in convincing him to bring his case to court. After the action had been introduced, the employer agreed on a settlement to pay damages to compensate for the discrimination. "Everything went very fast. [...] [The legal officer] sent a letter to the company; [the company] contested but did not give any justification; therefore, we initiated proceedings in the labor court, and a few days later, the company suggested a settlement. [...] It happened like that. [The Center's officers] were very proactive in bringing the case to the court." In comparison with other stories, his claim was particularly consistent over time as he relied exclusively on antidiscrimination law.

In contrast, Marie Petteni oscillated between different claims and strategies and did not go to court. She first asked to benefit from a medical part-time scheme and accommodation of her schedule. But after her school director had told her that she would be dismissed if she kept on asking for it, she was advised by the Disability Regional officer to contact the Center for Equal Opportunities to force the employer to fulfill her obligation. She filled out the Center's complaint form. A legal officer informed her that the refusal to adapt her classroom and schedule constituted discrimination and assisted her in her negotiation with the school director to obtain a reasonable accommodation. After a few months of protest, Marie Petteni had the impression that her employer reacted negatively to any request on her part, although she had received support from various organizations. She progressively felt more and more isolated 
from her colleagues and her relationship with her director worsened. When we met her, she was desperate about her situation and had decided that, although she had support from the Center for Equal Opportunities, she would not sue her director. She was really disappointed because she had great expectations about the power of the law but was of the opinion that in the end invoking the right to reasonable accommodation had not improved her situation. Furthermore, she had serious doubts about her ability to continue working. She had already compared her income with the social security benefits she could receive if she became unemployed. "They said that accommodation was a right, and that I could work if I felt able to work. But now, I wonder 'Am I still able to work?' Maybe I have to admit that I do not fit with the job anymore."

Another experience of legal mobilization is illustrated by the case of Charlotte Leroy, the woman employed in a hospital who had requested an adaptation of her tasks because of eyesight troubles. She was informed by her lawyer that she was entitled to reasonable accommodation and decided to go to court to contest the termination of her employment contract. She handled her legal procedure on her own, with the assistance of her lawyer. Interestingly, in her plea, she argued that this termination was in breach of both labor law provisions on workers encountering health problems and the right to reasonable accommodation based on disability. She thus invoked concomitantly both labor rights and antidiscrimination rights. ${ }^{14}$

These stories highlight two main factors that contributed to produce differentiated patterns in the trajectories of legal mobilization among our interviewees. First, prior awareness of disability rights, or the lack thereof, determined the ability of concerned individuals to characterize by themselves the injustice as discrimination. François Tiquet, who already had some knowledge of disability discrimination prohibition, immediately perceived the attitude of the employer as discrimination. Other workers, by contrast, were not initially aware that the injustice they experienced could be described as discrimination. They sought help from various sorts of professionals and it is these professionals who informed them that they could invoke antidiscrimination law. Second, the advice given and opinion expressed by mediating professionals on their case had, for most of our interviewees, a decisive impact on the trajectory of their mobilization and their decision whether or not to go to court. Most of them contacted in a first stage a trade union, the Disability Regional Office and/or a disability NGO and were advised by professionals from these organizations to seek help from the equality agency. Some, like François Tiquet, did not clearly envisage a legal action when they contacted the Center for Equal Opportunities but decided to bring their case to court because the agency encouraged them to do so. Other interviewees, like Bart Janssens, did not feel necessary to go to court because the Center helped them to negotiate with their employer. Yet, a minority of our interviewees disregarded the advice of the equality agency: Marie Petteni gave up on the idea of going to court even though the Center supported her claim. Conversely, another of our interviewees contacted a private lawyer and went to court, despite having been

\footnotetext{
${ }^{14}$ This reflects a larger trend: in most cases brought before labor courts in relation to an alleged denial of reasonable accommodation, complainants invoke both labor law provisions and the antidiscrimination legislation (Ringelheim 2018).
} 
told by the equality agency officer that in their opinion she could not claim to have been discriminated against.

Besides, these stories show how, through legal mobilization, workers develop sophisticated rights consciousness. Those who acquired knowledge of the new antidiscrimination framework did not necessarily abandon alternative discourses based on labor or social norms. Their cases illustrate how individuals may combine the new antidiscrimination framework with other, older, frames of reference, with different implications. Over the course of her conflict with her employer, Marie Petteni considered labor, antidiscrimination, and social rights one after the other. In her efforts to keep her job, she asked for the medical part-time scheme, then filed a formal complaint of discrimination with the equality agency, and ultimately started to consider ceasing to work and living on social benefits. As for Charlotte Leroy, she went to court but claimed concomitantly a violation of her labor rights and of her antidiscrimination rights.

\section{Experiencing Rights and Wrongs: Effects of Legal Mobilization on Workers ${ }^{15}$}

The experience of legal mobilization produces various lasting effects on workers with disabilities. Our findings show that it modifies not only the way they identify to collective categories and perceive injustice but also how they understand the capacity of law to remedy injustice and inequality. It also changes the way they understand their status in the workplace and in society as a whole. Legal mobilization creates expectations and hopes, but also an opportunity to receive support from various professionals in pursuing one's rights. In Rights at Work, McCann identified four types of impacts legal mobilization could have on rights consciousness and political empowerment: the individual empowerment, the collective empowerment, the solidarity as principle, and the new rights and entitlements (1994: 258269). Our study also reveals four types of effects legal mobilization may have on workers. However, our categories differ from the ones used by McCann. From the stories produced by workers with disabilities we interviewed, it emerges that legal mobilization has "nurtured a sophisticated and savvy practical legal consciousness" (1994: 258), but also that the process has, in many cases, reinforced a feeling of persistence and ineluctability of inequalities and exclusion.

\section{Empowerment and Reinforced Identification as Disabled}

For some workers, the legal mobilization contributed to their personal empowerment as individuals and the reinforcement of their identification as disabled. François Tiquet was very confident when he started to look for a job in Belgium after his experience abroad. He quickly realized that his disability was an obstacle to his inclusion in the labor market and decided to hide his visual impairment until the recruitment interview. He progressively lost confidence in his profile and skills. "I wondered if I was looking at the wrong places, or if I was doing wrong." When a retail company refused to hire him after he had explained that he had visual impairment, he believed that their attitude was obviously connected to his disability and immediately decided to contest this decision. Through the course of legal mobilization,

\footnotetext{
${ }^{15}$ This title makes reference to the seminal book Disability Rights and Wrongs (Shakespeare 2006).
} 
François Tiquet gained confidence in his competencies. He started to consider that the lack of response to his previous job applications was probably due to the fact that he had mentioned his disability in his application letters. He quickly found a job in another company, where he immediately asked for accommodation and believed that he was treated equally with his colleagues. Like the women interviewed by McCann, after this experience of mobilizing the law, he felt better respected by others, in his workplace and elsewhere, and had a better selfimage as a worker. In this process, he also strengthened his awareness of being a member of a group, that of people with disabilities, and started to attend the social activities organized by the disability association that helped him.

\section{Individual Empowerment Limited to One Specific Conflict}

In other cases, legal mobilization contributed to produce individual empowerment, but limited to one specific conflict. When he formally mobilized the law, Bart Janssens felt supported by many professionals who assisted him and acquired the conviction that his employer was under a legal duty to comply with his request. He considered that asserting his rights was a success as he obtained what he was asking for. However, even if the mobilization of the law contributed to his individual empowerment within the workplace and the reinforcement of his confidence in his ability to work, he perceived his victory as isolated and as the outcome of negotiation between one specific employer and one worker, rather than as a victory for disabled workers in general. "I obtained what I asked for in [this company]. But it is only because my boss was empathic towards me." This process, moreover, did not lead him to identify as disabled in his personal and social life.

\section{Reinforced Perception of Work and Disability as Mutually Exclusive}

The story of Marie Petteni reveals growing skepticism towards the ideal of inclusion of disabled workers. She initially thought of accommodation as a privilege but, through the course of legal mobilization, progressively endorsed the idea that it was a right. Those changes took place along with her gradual identification with the disability category. She started to have a lot of contact with the non-profit organization that assists people with multiple sclerosis and developed a feeling of solidarity with other members of the organization. However, given the school director's lack of receptiveness to her requests, she became very skeptical about the power of law to remedy the injustice she experienced. She started to doubt of her ability to continue her work. She realized that "having the law on [her] side did not help [her]." She was very thankful to the members of the disability non-profit organization for their assistance in her mobilization but considered that they had ambivalent attitudes towards her decision to keep on working. "They wanted us to be able to work, if we felt able to. But they also wanted us to be able to admit that we should also consider moving on to other social activities." Through the process of legal mobilization, she developed great expectations about inclusion in the workplace but her experience ultimately reinforced her perception that disability and employment were incompatible.

\section{Reinforced Perception of Inequalities Between Employers and Workers}

Lastly, some workers drew from their experience of legal mobilization the conclusion that the work relationship remains dominated by the imbalance of power between the employer and the worker and that there is not much the law can do about this. Over the course of her mobilization, Charlotte Leroy first increased her awareness of and faith in disability rights. When her lawyer informed her that she was entitled to reasonable accommodation, she 
became confident about the possibility for disabled workers to keep on working in an adapted environment. She decided to take her case to court. However, both the first instance and the appeal courts rejected her claim. Following these decisions, her perception of the social order as fundamentally unequal and of the workplace as a site of domination exerted by employers over workers was reinforced. She stated that her case was "lost in advance" because she contested a decision of her employer. She primarily interpreted these court decisions as proof of the partial attitude of labor judges "who are always on the side of employers," whatever the claim expressed by workers.

The four potential effects of legal mobilization that we have identified inspire much more pessimism in terms of empowerment and rights consciousness than the ones observed by McCann (1994). Of course, whether or not the workers obtained the accommodation they were aiming for does influence the impact left upon them by their experience of mobilizing the law. But beyond this element, two factors may possibly explain differences in the effects of legal mobilization. First, we can hypothesize that workers who take part in collective mobilization - like the women engaged in the pay equity movement studied by McCann - are more likely to nurture a feeling of empowerment than the ones who pursued their rights individually. Our interviewees, even though they received support from professionals working in disability NGOs, disability institutions or the equality agency, were not active in the disability rights movements. Their mobilization was not rooted in previous activism and, for most of them, in clear preexisting identification as disabled. Our research suggests that individual disputes without support from organizations with clear political objectives and without sustained group bonds are less likely to transform the feeling of disempowerment of those involved in the mobilization. Second, the variations we observe among our interviewees in terms of rights consciousness resulting from the mobilization may be correlated to different readings of their experience and different expectations about antidiscrimination law. François Tiquet and Marie Petteni perceived the injustice they faced as one instance of a collective problem, that of the structural exclusion of people with disability. Both had high expectations in the capacity of the antidiscrimination law to redress the situation. At the end of their mobilization, the former was reinforced in his initial perception whereas the latter was disappointed. By contrast, Bart Janssens did not see his personal case as reflecting the difficulties encountered by people with disability in general. He used antidiscrimination law strategically, because he learned it could be useful for him, but remained skeptical about the capacity of law to improve generally the situation of workers with disability or health problems. This attitude may be revealing of a broader phenomenon: since disability is an extremely diverse phenomenon, varying not only in the form it takes but also in the period in life in which it appears, it may be more difficult for workers with disabilities than for other minorities to interpret their personal experience as one instance of a structural problem of discrimination and, accordingly, to feel engaged in a collective struggle. The case of Bart Janssens is also indicative of the fact that, although the antidiscrimination framework promotes a new understanding of the relation between disability and work based on the idea of inclusion, the traditional approach, which considers disability and work in the ordinary labor market as mutually exclusive (Albiston 2005; Mor 2005; Stone 1984), is still largely entrenched in the practices of employers, unions and disability organizations as well as in workers' representations. 


\section{CONCLUSION}

This article examined how the coexistence of, and interplay among, social, labor, and antidiscrimination legal norms relating to disability impact on concrete legal mobilization. It analyzed how different people with disabilities have mobilized the law to obtain reasonable accommodation in the workplace in Belgium.

The analysis of stories produced by workers who mobilized the law contrasts with existing disability rights studies in three ways. First, it questions the commonly shared idea that a new, uniform, model of disability policy based on the antidiscrimination framework is now in place. Further developing the argument made by Heyer, our study shows that in Belgium preexisting models of disability policies based on social protection and labor provisions, which are still in force, continue to influence individuals' experience of disability in the workplace and, accordingly, legal mobilization of workers with disabilities. Workers who were refused accommodation rarely perceived the situation as discrimination initially. In most cases, they first understood the dispute as a conflict involving traditional labor rights. It is only after they contacted professionals, such as disability organization employees, union delegates, lawyers or the equality agency, that they reframed the issue as involving discrimination based on disability. Our study thus reveals the persisting significance, in the Belgian context, of labor rights for this category of workers. This has important implications for the process of identification with disability. Whereas social rights do recognize the notion of disability, although relying on a more restrictive definition than antidiscrimination rights, labor rights ignore this concept. Instead, labor law only acknowledges the category of "workers unable to perform their work". This means that workers who fall into the category of "persons with disabilities" under antidiscrimination law can find an alternative identity within labor law, associated with different, but more restricted, rights. This complicates further the question of law's impact on the process of identification with disability. Part of the interviewees identified as disabled before engaging with the law and felt reinforced in this preexisting identity when discovering the antidiscrimination legal framework. Others, by contrast, did not identify with disability before facing difficulties at work. Among the latter, some evolved in their feeling of identity after learning they were considered disabled by the law and, as such, were entitled to claim reasonable accommodation, whereas others, while invoking the legal notion of "disability" in order to obtain the accommodation they wanted, did not consider this category as reflecting their "true" identity and continued to identify as workers with health problems, thus relying on the concepts of labor law. Thus, the interplay of law and understanding of changing physical conditions in a context where antidiscrimination, labor and social rights coexist produces varying results.

Second, our study also differs from most research in the field of disability legal studies in that the latter usually focus on the content of policies and legislation, while our contribution examines how different, coexisting, policies and legal norms shape concrete legal mobilization. We have focused on three dimensions of the mobilization: identification with the collective categories of workers and/or persons with disabilities; the process of mobilizing of the law, and the effects of such mobilization on individuals' legal consciousness and feeling of empowerment. We have shown that through the course of legal mobilization, as they interacted with various professionals, our interviewees modified their understanding of the situation they faced, but also their self-identification and rights consciousness. Ultimately, after this experience of mobilization, some felt empowered and had increased confidence in 
law's capacity to improve the situation of workers with disabilities, while others, on the contrary, were reinforced in their feeling that the exclusion of disabled persons from the workplace was ineluctable, whatever the law says.

Thirdly, while previous studies on disability rights litigation were generally concerned with large mobilization supported by disability rights activist organizations with a clear political objective, strategically using litigation in order to promote the antidiscrimination model of disability, our research deal with low-scale mobilization, initiated by individual workers who only sought to improve their personal situation. Our findings indicate that in Belgium, until now, legal mobilization of workers seeking reasonable accommodation have been of the second type rather than the first.

This article suggests several lines for further research. The hypotheses developed here about the interaction between social, labor, and antidiscrimination rights in the context of legal mobilization of workers with disabilities, and more especially the persisting importance of labor rights and its implications in terms of identification or non-identification with disability, could be tested in other countries with strong labor law traditions, for instance, the Scandinavian countries, with a view to developing a broader theoretical perspective on how the interplay between a plurality of legal norms impacts on how individuals mobilize the law. Furthermore, regarding the effects of mobilization on the feeling of empowerment of individuals concerned, the difference we observe between the workers we studied, who all engaged in individual, isolated, disputes, and movements analyzed by other authors, who were involved in collective legal mobilization, could be explored further in the context of other forms of legal mobilization.

\section{Appendix}

\begin{tabular}{|c|c|c|c|c|}
\hline \multicolumn{5}{|c|}{ Table 1. Four stories } \\
\hline & $\begin{array}{lr}\text { Bart } & \text { Janssens } \\
\text { (construction worker) }\end{array}$ & $\begin{array}{l}\text { Marie Petteni } \\
\text { (school teacher) }\end{array}$ & $\begin{array}{l}\text { Charlotte Leroy } \\
\text { (administrative } \\
\text { secretary) }\end{array}$ & $\begin{array}{l}\text { François Tiquet } \\
\text { (sales manager) }\end{array}$ \\
\hline $\begin{array}{l}\text { Self- } \\
\text { identification }\end{array}$ & $\begin{array}{ll}\text { As worker with } \\
\text { health problems }\end{array}$ & $\begin{array}{l}\text { Progressively with } \\
\text { disability as worker }\end{array}$ & $\begin{array}{lr}\text { As disabled } & \text { despite } \\
\text { being } & \text { denied } \\
\text { recognition } & \text { as } \\
\text { disabled under } & \text { social } \\
\text { legislation } & \end{array}$ & $\begin{array}{l}\text { With disability as job } \\
\text { applicant }\end{array}$ \\
\hline $\begin{array}{l}\text { Perception of } \\
\text { the injustice }\end{array}$ & $\begin{array}{l}\text { Lack of reactivity of } \\
\text { his employer when } \\
\text { faced with his } \\
\text { condition }\end{array}$ & $\begin{array}{l}\text { Lack of reactivity of } \\
\text { her employer when } \\
\text { faced with her } \\
\text { disability }\end{array}$ & $\begin{array}{l}\text { Refusal of her } \\
\text { employer to adapt her } \\
\text { tasks to her disability }\end{array}$ & $\begin{array}{l}\text { Discrimination in the } \\
\text { hiring process based } \\
\text { on disability }\end{array}$ \\
\hline $\begin{array}{l}\text { First contact } \\
\text { with } \\
\text { professionals }\end{array}$ & $\begin{array}{l}\text { Labor union and } \\
\text { occupational } \\
\text { physician }\end{array}$ & $\begin{array}{l}\text { Occupational } \\
\text { physician, Disability } \\
\text { Regional Office }\end{array}$ & $\begin{array}{l}\text { Disability Regional } \\
\text { Office }\end{array}$ & $\begin{array}{l}\text { Disability } \\
\text { organization }\end{array}$ \\
\hline $\begin{array}{l}\text { Assertion of } \\
\text { social, labor, }\end{array}$ & $\begin{array}{l}\text { Transfer to another } \\
\text { department, }\end{array}$ & $\begin{array}{l}\text { Negotiation } \\
\text { "ordinary" }\end{array}$ & $\begin{array}{l}\begin{array}{l}\text { Contestation of the } \\
\text { termination }\end{array} \\
\text { of }\end{array}$ & $\begin{array}{l}\text { Compensation for } \\
\text { denial of reasonable }\end{array}$ \\
\hline
\end{tabular}




\begin{tabular}{|c|c|c|c|c|}
\hline $\begin{array}{l}\text { and/or } \\
\text { antidiscrimin } \\
\text { ation rights }\end{array}$ & $\begin{array}{l}\text { reasonable } \\
\text { accommodation }\end{array}$ & $\begin{array}{l}\text { reasonable } \\
\text { accommodation, } \\
\text { social protection. }\end{array}$ & $\begin{array}{l}\text { employment contract } \\
\text { and denial of } \\
\text { reasonable } \\
\text { accommodation. }\end{array}$ & accommodation \\
\hline $\begin{array}{l}\text { Legal } \\
\text { Mobilization }\end{array}$ & $\begin{array}{l}\text { Formal protest and } \\
\text { threat to turn to the } \\
\text { labor court }\end{array}$ & $\begin{array}{l}\text { Formal protest and } \\
\text { refusal to turn to the } \\
\text { courtroom }\end{array}$ & $\begin{array}{l}\text { Legal action taken } \\
\text { before the lower and } \\
\text { the appeal labor court }\end{array}$ & $\begin{array}{l}\text { Legal action initiated } \\
\text { before the labor } \\
\text { court, followed by } \\
\text { negotiation of a } \\
\text { settlement }\end{array}$ \\
\hline $\begin{array}{l}\text { Effects of } \\
\text { legal } \\
\text { mobilization }\end{array}$ & $\begin{array}{l}\text { Individual } \\
\text { empowerment limited } \\
\text { to one specific } \\
\text { conflict }\end{array}$ & $\begin{array}{l}\text { Reinforced } \\
\text { perception of work } \\
\text { and disability as } \\
\text { mutually exclusive }\end{array}$ & $\begin{array}{lr}\text { Reinforced } & \\
\text { perception } & \text { of } \\
\text { inequalities } & \text { between } \\
\text { employers } & \text { and } \\
\text { workers } & \end{array}$ & $\begin{array}{l}\text { Empowerment, } \\
\text { reinforced } \\
\text { identification with } \\
\text { disability }\end{array}$ \\
\hline
\end{tabular}

\begin{tabular}{|l|l|}
\hline Table 2. Explanatory variables \\
\hline $\begin{array}{l}\text { Perception of } \\
\text { injustice }\end{array}$ & Self-identification as a disabled person or as a worker \\
\cline { 2 - 3 } & Work environment (blue-collar v. white-collar workers) \\
\hline $\begin{array}{l}\text { Process of } \\
\text { mobilization }\end{array}$ & Prior awareness or non-awareness of disability rights \\
\cline { 2 - 3 } & Advise and opinion of mediating professionals \\
\hline $\begin{array}{l}\text { Effects of } \\
\text { mobilization }\end{array}$ & Collective v. individual mobilization \\
\cline { 2 - 2 } & Expectations about antidiscrimination law \\
\hline
\end{tabular}

\section{References}

Albiston, C. (2005). Bargaining in the Shadow of Social Institutions: Competing Discourses and Social Change in Workplace Mobilization of Civil Rights. Law \& Society Review, 39(1), 11-50.

Amiraux, V., \& Guiraudon, V. (2010). Discrimination in Comparative Perspective: Policies and Practices. American Behavioral Scientist, 53(12), 1691-1714.

Aucante, Y., \& Baudot, P-Y. (2018). Introduction: Implementing Disability Rights in National Contexts: Norms, Diffusion, and Conflicts. Social Policy \& Society, 17(1), 87-100.

Bagenstos, S. (2009). Law and the Contradictions of the Disability Rights Movement. New Haven: Yale University Press.

Barnes, C., \& Mercer, G. (2005). Disability, Work, and Welfare: Challenging the Social Exclusion of Disabled People. Work, Employment, and Society, 19(3), 527-545.

Baudot, P.-Y. (2018). Layering Rights: The Case of Disability Policies in France (20062016). Social Policy \& Society, 17(1), 117-131. 
Befort, S. (2018). The Declining Fortunes of American Workers: Six Dimensions and an Agenda for Reform. Florida Law Review, 70, 189-223.

Burke, T. (2004). The European Union and the Diffusion of Disability Rights. In M. Levin \& M. Shapiro (Eds.), Translating Policy-Making in an Age of Austerity: Diversity and Drift. Washington: Georgetown University Press, 158-176.

Burke, T., \& Barnes, J. (2016). The Civil Rights Template and the Americans with Disabilities Act: A Socio-Legal Perspective on the Promise and Limits of Individual Rights. In L. Dodd (Ed.), The Rights Revolution Revisited: Institutional Perspectives on the Role of Private Enforcement of Civil Rights in the US. New York: Cambridge University Press.

Cohu, S., Lequel-Slama, D., \& Velche, D. (2005). Politiques du Handicap dans Cinq Pays Européens. Revue Française Des Affaires Sociales, 2, 9-33.

Dorfman, D. (2017). Re-Claiming Disability: Identity, Procedural Justice, and the Disability Determination Process. Law \& Social Inquiry, 42(1), 195-231.

Driedger, D. (1989). The Last Civil Rights Movement: Disabled Peoples' International. New York: St. Martin's Press.

Engel, D., \& Munger, F. (1996). Rights, Remembrance, and the Reconciliation of Difference. Law \& Society Review, 30(1), 7-54.

Engel, D., \& Munger, F. (2003). Rights of Inclusion: Law and Identity in the Lives of American with Disabilities. Chicago: University of Chicago Press.

Ewick, P., \& Silbey, S. (1998). The Common Place of Law: Stories from Everyday Life. Chicago: University of Chicago Press.

Faniel, J., \& Vandaele, K. (2012). Implantation Syndicale et Taux de Syndicalisation (20002010). Courrier Hebdomadaire Du CRISP, 2146-2147.

Felstiner, W., Abel, R., \& Sarat, A. (1981). The Emergence and Transformation of Disputes: Naming, Blaming, Claiming... Law \& Society Review, 15(3/4), 631-654.

Fleischer, D., \& Zames, F. (2011). The Disability Rights Movement: From Charity to Confrontation. Temple University Press.

Goffman, E. (1963). Stigma. Englewood Cliffs: Printice-Hall.

Halvorsen, R., Hvinden, B., Bickenbach, J., Waldschmidt, A., Sturm, A., Karacic, A., \& Dins, T. (Eds.). (2017). The Changing Disability Policy System. Active Citizenship Policy in Europe. London: Routledge.

Handler, J. F. (1978). Social Movements and the Legal System: A Theory of Law Reform and Social Change. New York: Academia Press.

Heyer, K. (2007). A Disability Lens on Socio-legal Research: Reading Rights of Inclusion from a Disability Studies Perspective. Law and Social Inquiry, 32(1), 261-293. 
Heyer, K. (2015). Rights Enabled. The Disability Revolution from the US to Germany and Japan, to the United Nations. Ann Arbor: University of Michigan Press.

Kelemen, D. (2011). Eurolegalism: The Transformation of Law and Regulation in the European Union. Cambridge: Harvard University Press.

Kelemen, D., \& Vanhala, L. (2010). The shift to the rights model of disability in the EU and Canada. Regional and Federal Studies, 20(1), 1-18.

Lejeune, A., Hubin, J., Ringelheim, J., Robin-Olivier, S., Schoenaers, F., \& Yazdanpanah, H. (2017). Handicap et aménagements raisonnables au travail. Importation et usages d'une catégorie juridique en France et en Belgique. Mission de recherche Droit et Justice. http://www.gip-recherche-justice.fr/publication/amenagements-raisonnables-au-travailimportation-et-usages-dune-categorie-juridique-en-france-et-en-belgique/

Lejeune, A., \& Orianne, J-F. (2014). Choisir des Cas Exemplaires: la Strategic Litigation face aux Discriminations. Déviance et Société, 34(1), 55-76.

Mabbett, D. (2005). The Development of Rights-based Social Policy in the European Union: The Example of Disability Rights. Journal of Common Market Studies, 43, 97-120.

Marshall, A-M. (2003). Injustice Frames, Legality, and the Everyday Construction of Sexual Harassment. Law and Social Inquiry, 28(3), 659-689.

McCann, M. (1994). Rights at Work: Pay Equity Reform and the Politics of Legal Mobilization. Chicago: University of Chicago Press.

Merry, S. E. (1990). Getting Justice and Getting Even: Legal Consciousness among WorkingClass Americans. Chicago: Chicago University Press.

Miller, R., \& Sarat, A. (1981). Grievances, Claims, and Disputes: Assessing the Adversary Culture. Law \& Society Review, 15(3/4), 525-566.

Morrill, C., Edelman, L., Tyson, K., \& Arum, R. (2010). Legal Mobilization in Schools: the Paradox of Rights and Race Among Youth. Law \& Society Review, 44(3/4), 651-694.

Mor, S. (2005). Between Charity, Welfare, and Warfare: A Disability Legal Studies Analysis of Privilege and Neglect in Israeli Disability Policy. Yale Journal of Law and the Humanities, $18(2), 63-136$.

Neven, J.-F. (2013). Le Droit Européen de la Non-Discrimination: un Impact Décisif en faveur d'une Obligation Généralisée de Reclassement Professionnel? In M. Davagle, Le maintien au travail de travailleurs devenus partiellement inaptes, Anthemis, 35-60.

Oliver, M. (1996). Understanding Disability: from Theory to Practice. Basingstoke: Macmillan.

Quinn, G., \& Flynn, E. (2012). Transatlantic Borrowings: The Past and Future of EU NonDiscrimination Law and Policy on the Ground of Disability. American Journal of Comparative Law, 60(1), 23-48. 
Revillard, A. (2017a). La Réception des Politiques du Handicap : une Approche par Entretiens Biographiques. Revue Française de Sociologie, 58, 71-95.

Revillard, A. (2017b). Social movements and the politics of bureaucratic rights enforcement: insights from the allocation of disability rights in France. Law \& Social Inquiry, 42(2), 450478 .

Ringelheim, J. (2018). La Réception en Droit Belge de l'Obligation d'Aménagement Raisonnable en faveur des Travailleurs Handicapés. Journal des Tribunaux, 6726, 309-319.

Rosenberg, G. (1993). The Hollow Hope: Can Courts Bring About Social Change? Chicago: University of Chicago Press.

Setzer, J., Vanhala, L., Climate Change Litigation: A Review of Research on Courts and Litigants in Climate Governance, WIREs Climate Change, 10(3), https://doi.org/10.1002/wwc.580.

Shakespeare, T. (2006). Disability Rights and Wrongs. London: Routledge.

Shapiro, J. (1994). No Pity: People with Disabilities Forging a New Civil Rights Movement. Times Books.

Stone, D. (1984). The Disabled State. Philadelphia: Temple University Press.

Vanhala, L. (2009). Anti-Discrimination Policy Actors and their Use of Litigation Strategies: the Influence of Identity Politics. Journal of European Public Policy, 16(5), 738-754.

Vanhala, L. (2011). Making Rights a Reality? Disability Rights Activists and Legal Mobilization. Cambridge: Cambridge University Press.

Vanhala, L. (2015). The Diffusion of Disability Rights in Europe. Human Rights Quarterly, 37(4), 831-853.

Vrancken, D., \& Bartholomé, C. (2004). L'Accompagnement des Personnes Handicapées en Belgique: un Concept au Coeur des Nouvelles Politiques Sociales. Nouvelles Pratiques Sociales, 17(1), 98-111.

Waddington, L. (1996). Reassessing the Employment of People with Disabilities in Europe : From Quotas to Anti-discrimination Laws. Comparative Labour Law Journal, 18, 62-191.

Waddington, L. (2008). When is it reasonable for Europeans to be Confused : Understanding When a Disability Accommodation is «Reasonable» from a Comparative Perspective. Comparative Labor Law \& Policy Journal, 29, 317-340.

Waldschmidt, A. (2009). Disability Policy of the European Union: The Supranational Level. European Journal of Disability Research, 3, 8-23. 